удК 342.9

DOI https://doi.org/10.32837/pyuv.v1i4(29).418

\author{
B. М. $\epsilon \partial н а \kappa$ \\ orcid.org/0000-0001-7245-1618 \\ кандидат юридичних наук, \\ доиент кафедри крилінального процесу \\ Дніпропетровського державного університету внутрішніх справ
}

\title{
ШЛЯХИ ВДОСКОНАЛЕННЯ ФОРМ І МЕТОДІВ ВЗАЄМОДІЇ ОРГАНІВ ПРОКУРАТУРИ УКРАЇНИ З ІНШИМИ ПРАВООХОРОННИМИ ОРГАНАМИ ДЕРЖАВИ
}

Постановка проблеми. Сьогодні однією з найгостріших проблем правоохоронної діяльності є стрімке погіршення криміногенної ситуації в Україні, розгул і безкарність криміналітету, як результат, беззахисність громадян, порушення їхнього права на захист від злочинних посягань. Тому й не дивно, що наша країна стрімко скочується до рівня найбільш криміногенних держав світу, про що свідчить і відповідна статистика: згідно 3 міжнародним рейтингом найбезпечніших для життя країн за 2016 і 2017 роки, Україна посідала, відповідно, 154 і 156 місце зі 163-х позицій, знаходячись між Центральною Африканською Республікою й Суданом. Згідно з іншим рейтингом - надійності поліцейських служб, Україна у 2017-2018 pр. знаходилася на 101 місці зі 137 держав. Нас обігнали за цим показником навіть такі країни, як Замбія, Ямайка, Уганда та Малави [1]. Разом із тим, розмірковуючи над шляхами вдосконалення адміністративно-правових засад діяльності прокуратури як правоохоронного органу, не можемо оминути питання поліпшення

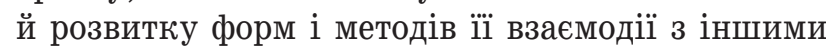
правоохоронними органами.

Стан дослідження. Питання взаємодії органів прокуратури неодноразово потрапляло в поле зору науковців, котрі досліджували діяльність цього відомства в розрізі окремих проблематик. У цьому контексті варто вказати наукові праці Н.П. Осипова, В.Д. Водніка, Г.П. Клімова, Н.П. Осипової, Ю.П. Сурміна, В.Д. Бакуменка, А.М. Михненка, Ю.В. Ковбасюка, В.П. Трощинського, Л.В. Бородича, С.П. Кондракова й багатьох інших. Водночас справедливим буде відзначити, що, незважаючи на чималу кількість наукових розробок, у юридичній літературі відсутнє комплексне дослідження, присвячене вдосконаленню форм і методів взаємодії органів прокуратури України з іншими правоохоронними органами держави.

Саме тому мета статті - визначити шляхи вдосконалення форм і методів взаємодії органів прокуратури України з іншими правоохоронними органами держави.

Виклад основного матеріалу. Починаючи наукове дослідження, відзначимо, що взаємодію прокуратури з правоохоронними органами можна розглядати у вузькому та більш широкому сенсі. У першому випадку вона, тобто взаємодія, являє собою діяльність, що здійснюється прокуратурою спільно, узгоджено з органами держави, спеціально створеними для протидії протиправній поведінці, у тому числі злочинності, підтримання режиму законності та стану правопорядку у відповідних сферах суспільного життя, наділеними у зв'язку із цим специфічними повноваженнями, що в тому числі передбачають можливість застосування в установлених законом випадках заходів примусу. У більш широкому розумінні така взаємодія передбачає співпрацю прокуратури 3 низкою інших органів держави, що так чи інакше роблять на нормотворчому, правозастосовному, освітньо-виховному та іншому рівнях свій внесок у діяльність 3 охорони й захисту життя та здоров'я, прав, свобод і законних інтересів людини, інших суспільних цінностей, інтересів держави й суспільства загалом. Утім така діяльність для цих органів має другорядний, супутній характер, вона не передбачає прямого здійснення ними правоохоронних заходів, у тому числі з використанням примусу.

Розмірковуючи над шляхами вдосконалення форм і методів взаємодії органів прокуратури України з іншими правоохоронними органами держави, варто звернути увагу на такі аспекти:

1. Відсутність належного законодавчого врегулювання форм і методів взаємодії прокуратури з правоохоронними органами. У цьому випадку йдеться про взаємодію зазначених суб'єктів поза межами кримінального процесу, оскільки, по-перше, нас цікавить її (взаємодії) адміністративно-правовий бік, а по-друге, взаємовідносини прокурора й інших правоохоронних органів і їх посадових осіб у межах кримінальної процесуальної діяльності мають досить чітку й сувору регламентацію на рівні Закону. Виходячи з аналізу чинного Закону України «Про прокуратуру» від 14.10.2014 № 1697-VII, основною формою досліджуваної взаємодії є координація. Зокрема, у ч. 2 ст. 25 цього Закону закріплено, що Генеральний прокурор, керівники відповідних прокуратур, ïx перші заступники та заступники відповідно до розподілу обов'язків координують діяльність 
правоохоронних органів відповідного рівня у сфері протидії злочинності. Основною формою координації є проведення координаційних нарад iз керівниками правоохоронних органів, на яких заслуховується інформація щодо їхньої діяльності у сфері протидії злочинності. Рішення координаційної наради є обов'язковим до виконання всіма зазначеними в ньому правоохоронними органами. Порядок та інші форми координації затверджуються наказом Генерального прокурора [2]. Варто відмітити, що серед дослідників немає єдності з приводу того, як варто співвідносити координацію та взаємодію, деякі з них акцентують увагу на необхідності чітко розмежовувати ці поняття. Так, скажімо, В.В. Чумак, розмежовуючи взаємодію та координацію, зазначає, що метою координації є створення відповідного режиму відносин між суб'єктами, за якого виконання ними узгоджених завдань досягається 3 найменшими витратами сил, засобів і часу. У свою чергу, метою ж взаємодії є здійснення певних узгоджених дій, спрямованих на досягнення конкретного результату. Зокрема, складення комплексних планів, підготовка управлінських рішень, координаційні наради належать до координації. А здійснення спільних заходів щодо затримання злочинця, проведення комплексних заходів щодо забезпечення прикордонної безпеки є взаємодією [3, с. 164]. За позицією, яку висловлює Ю.В. Собко, «взаємодія» та «координація» співвідносяться як загальне й часткове, де взаємодія є загальним, а координація - частковим, оскільки в більшості випадків координація розглядається як організація взаємодії (за часом, суб’єктами, територією тощо). Крім того, на відміну від взаємодії, під час якої суб'єкти рівні, тобто не мають владних повноважень один стосовно одного, під час координації один із суб'єктів, яких, як правило, не менше ніж троє, є координатором (організатором) спільної діяльності, у зв'язку з чим має право давати обов' язкові для виконання вказівки іншим її учасникам [4, с. 112]. У свою чергу, Д.Г. Заброда підкреслює, що координація та взаємодія мають однакову мету - узгодження дій. Так, якщо метою координації є створення відповідного режиму відносин між суб'єктами, за якого виконання ними узгоджених завдань досягається 3 найменшими витратами сил, засобів і часу, то метою взаємодіїздійснення певних узгоджених дій, спрямованих на досягнення конкретного результату [5, с. 238].

Отже, ураховуючи позиції цих та інших дослідників, а також спираючись на аналіз відповідних чинних нормативно-правових актів, уважаємо, що координація в контексті діяльності органів прокуратури є особливим різновидом їх взаємодії з іншими суб'єктами правоохоронної діяльності, передусім правоохоронними органами, оскільки через координаційні заходи реалізується значна частина позапроцесуальної співпраці досліджуваних суб'єктів. Саме в межах координаційної діяльності вони виробляють та погоджують спільні дії щодо протидії злочинності й інших важливих питань.

Тож, акцентуючи увагу на досить поверховій законодавчій регламентації форм і методів указаної взаємодії, варто відмітити, що на законодавчому рівні практично не має положень, що визначають матеріально-правові та процедурні засади організації й здійснення такої взаємодії. У чинному Законі України «Про прокурату» міститься лише кілька положень, присвячених координації, однак і вони не надають чіткого уявлення ані про ï̈ сутність і зміст, ані форми й напрями координації. Дещо прояснюють ці питання певні підзаконні нормативно-правові акти, такі як спільний Наказ Генерального прокурора України та керівників правоохоронних органів «Про координацію діяльності правоохоронних органів по боротьбі із злочинністю та корупцією» від 26.04.2012 № 43/375/166/353/284/241/290/236 [6] і Наказ ГПУ «Про координацію діяльності правоохоронних органів у сфері протидії злочинності та корупції» від 16.01.2013 № 1/1гн [7]. Зокрема, у першому нормативно-правовому акті встановлено, що основною формою координації є проведення координаційної наради керівників правоохоронних органів. Окрім того, можуть використовуватися такі форми координації: проведення спільних засідань колегій правоохоронних органів; проведення міжвідомчих нарад за участю керівників правоохоронних органів, органів виконавчої влади та місцевого самоврядування; видання спільних наказів, указівок, інформаційних листів та інших документів організаційного й методичного характеру; обмін інформацією з питань стану злочинності й корупції; розроблення та здійснення узгоджених заходів з метою виявлення, припинення й профілактики злочинів і корупційних діянь, а також усунення причин та умов, що сприяли їх учиненню; спільні виїзди до регіонів для проведення узгоджених заходів, перевірок і надання допомоги правоохоронним органам на місцях; вивчення позитивного досвіду з питань запобігання й протидії злочинності та корупції, упровадження його в практичну діяльність правоохоронних органів; утворення спільних слідчо-оперативних груп для розкриття й розслідування окремих тяжких та особливо тяжких злочинів; взаємне використання можливостей правоохоронних органів для підготовки й навчання кадрів, підвищення їхньої кваліфікації; проведення спільних семінарів, конференцій та інших навчально-практичних заходів; розроблення пропозицій з питань удосконалення правового регулювання запобігання та протидії злочинності й корупції; спільне ініціювання та проведення наукових досліджень у сфері боротьби 
зі злочинністю й корупцією [6]. Утім на практиці більшість із цих форм координації не використовуються. Та й до ефективності основної форми координації - проведення координаційної наради керівників правоохоронних органів - $є$ низка зауважень, як-то: поверховий підхід до обговорення проблемних питань і небажання суб'єктів заглиблюватися в їх сутність; відсутність конкретики в прийнятих рішеннях, які досить часто зводяться до констатації й без того відомих обставин і цитування законодавчих положень.

Переконані, що з метою поліпшення якості координації як форми взаємодії прокуратури 3 правоохоронними органами необхідно на законодавчому (а не підзаконному) рівні більш змістовно та детально врегулювати питання взаємодії прокуратурою з іншими правоохоронними органами в межах координаційної роботи. Зокрема, необхідно визначити цілі й завдання, принципи та напрями, ключові форми й методи співпраці сторін у межах зазначеної координації. Також необхідно визначити загальні права й обов'язки взаємодіючих сторін, окрема увага має бути приділена питанням наслідків і відповідальності невиконання (неналежного виконання) правоохоронними органами спільно розроблених та узгоджених програм, заходів.

2. Необхідність розширення кола форм і методів взаємодії прокуратури з іншими правоохоронними органами в напрямі підвищення правової обізнаності й правової культури населення. Необхідність активного розвитку взаємодії досліджуваних суб'єктів у формі спільної освітньо-виховної та інформаційно-пропагандистської роботи зумовлена таким:

- по-перше, правова неосвіченість і правовий нігілізм є одними з тих факторів, що сприяють розвитку злочинності й інших форм протиправної поведінки. Правовий нігілізм - це негативне ставлення до права, закону, правових форм організації суспільних відносин. Форми вираження правового нігілізму: пряме навмисне порушення чинного законодавства (небезпечний вид правового нігілізму); масове недотримання юридичних приписів, коли суб'єкти не співвідносять свою поведінку з вимогами правової норми; протиріччя в різних нормативно-правових актах («війна законів»); підміна законності політичною, ідеологічною доцільністю; конфронтація представницьких і виконавчих органів влади на всіх рівнях; порушення прав людини [8];

- по-друге, в Україні рівень довіри населення до прокуратури й інших правоохоронних органів надзвичайно низький, порівняно 3 іншими інституціями держави та громадянського суспільства. Так, за даними опитування, проведеного Соціологічною групою «Рейтинг» у жовтні 2019 року, найбільше громадяни України сьо- годні довіряють волонтерам (69\%), ветеранам ATO $(67 \%)$, Президенту України $(66 \%)$ та армії $(65 \%)$. Також високий рівень довіри має церква $(56 \%)$. Громадським організаціям довіряють $48 \%$ респондентів, міським/сільським головам $47 \%$, Національній гвардії - $46 \%$, Уряду $-45 \%$, Верховній Раді - 44\%, місцевим $3 \mathrm{MI}-43 \%$, загальнонаціональним 3MI $-42 \%$, Службі безпеки України $-38 \%$, обласним державним адміністраціям - $32 \%$. Іншим інституціям швидше не довіряють, аніж довіряють. Так, поліції не довіряють $49 \%$, довіряють - $31 \%$, прикордонній службі $41 \%$ і $23 \%$ відповідно, Державному бюро розслідувань - $41 \%$ і $23 \%$, податковим органам - $50 \%$ і $20 \%$, митним органам - $51 \%$ і $19 \%$, НАБУ $-49 \%$ і $17 \%$, Національному агентству з питань запобігання корупції - 48\% і 15\% . Найбільше українці не довіряють органам прокуратури $(62 \%)$ та судам $(66 \%)$. Довіряють їм лише $14-15 \%$ [9]. Згідно 3 даними дослідження, проведеного експертами Центру Разумкова, найчастіше громадяни України висловлюють довіру волонтерським організаціям (їм довіряють $68 \%$ опитаних), церкві $(61 \%)$, Збройним силам України (61\%), Державній службі з надзвичайних ситуацій (57\%), добровольчим батальйонам $(56 \%)$. До інституцій, яким довіра висловлюється частіше, ніж недовіра, належать також Державна прикордонна служба (їй довіряють $52 \%$ опитаних, не довіряють - 33\%), Національна гвардія України (відповідно, 49\% і 35\%), ЗМІ України (відповідно, $47 \%$ і $41 \%$ ), громадські організації (відповідно, $46 \%$ і $39 \%$ ). Недовіра найчастіше висловлюється Верховній Раді України ( $82 \%$ їй не довіряють), державному апарату (чиновникам) (81\%), 3MI Росіі $(79 \%)$, політичним партіям $(76 \%)$, судовій системі $(75 \%)$, Уряду України $(74 \%)$, комерційним банкам $(72 \%)$, прокуратурі $(71 \%)$, Президенту України $(69 \%)$, Спеціалізованій антикорупційній прокуратурі (69\%), Національному антикорупційному бюро України (НАБУ) (68\%), Національному агентству з питань запобігання корупції (НАЗК) (68\% ), Верховному Суду (67\%), місцевим судам $(67 \%)$, Антикорупційному суду $(66 \%)$, Конституційному Суду $(65 \%)$, Національному банку України (63\% ) [10]. 3 метою підвищення рівня правової свідомості та правової культури населення, поваги й авторитету правоохоронних органів серед населення прокуратура й інші суб'єкти правоохоронної системи мають спільно виробити та забезпечити послідовну й ефективну реалізацію заходів із правовиховного впливу на населення, як загалом, так й окремі соціальні групи.

3. Важливим моментом удосконалення й розвитку форм і методів взаємодії органів прокуратури України з іншими правоохоронними органами держави є вироблення системи оцінювання їхньої 
ефективності та дієвості. Оцінювання результатів діяльності є вирішальним чинником у визначенні того, чи досягла певна програма своїх цілей. Головне питання оцінювання полягає в тому, чи політика або програма змінює становище на краще, чи має вплив [11, с. 85]. Розробляючи означену систему оцінювання, варто особливу увагу приділити критеріям, з огляду на які буде проводитися вимірювання якості й ефективності взаємодії, як загалом, так і їі окремих форм і напрямів. Важливо відмітити, що такими критеріями мають бути не лише офіційні статистичні дані, а й інші показники, як-то: думка громадськості (пересічних громадян, інститутів громадянського суспільства); думка керівників взаємодіючих органів і виконавців спільних заходів.

Висновки. Отже, взаємодія є важливою засадою належної реалізації прокуратурою свого функціонального призначення як правоохоронного органу, адже вона є не знеособленою інституцією, а структурною ланкою національної правоохоронної системи, тому частина завдань, функцій i повноважень прокуратури передбачають її активну взаємодію з іншими правоохоронними органами задля забезпечення більш ефективного досягнення цілей правоохоронної діяльності. Аналіз нормативно-правового підгрунтя цієї взаємодії та наукових поглядів на її проблематику свідчать про те, що вона (взаємодія) сьогодні має низку прогалин як на законодавчому, так і практичному рівнях, що негативно позначається на якості й дієвості означеної взаємодії. Запропоновані в дослідженні кроки мають на меті вдосконалити форми й методи досліджуваної взаємодії та, відповідно, підвищити її ефективність і результативність.

\section{Jimepamypa}

1. Баганець О. Провальні реформи. Юридичний вісник України. URL: https://yvu.com.ua/provalnireformy.

2. Про прокуратуру : Закон України від 14.10.2014 № 1697-VII. URL: https://zakon.rada.gov. ua/laws/show/1697-18.

3. Чумак В.В. Взаємодія та координація між суб'єктами охорони державного кордону. Право $і$ без пека. 2011. № 2. C. 161-165.

4. Собко Ю.В. Сутність та особливості правоохоронної діяльності як об'єкта координаційного впливу. Право і безпека. 2009. № 5. С. 112-115.

5. Заброда Д.Г. Розмежування категорій «взаємодія» та "координація» у галузі боротьби з корупцією: теоретичний вимір. Науковий вісник Юридичной акаделії Міністерства внутрішніх справ. 2005. № 4 . C. $233-239$.

6. Про координацію діяльності правоохоронних органів по боротьбі із злочинністю та корупцією : Спільний наказ Генерального прокурора України та керівників правоохоронних органів від 26.04.2012 № $43 / 375 / 166 / 353 / 284 / 241 / 290 / 236$. URL: https:// zakon.rada.gov.ua/rada/show/v0043900-12.

7. Про координацію діяльності правоохоронних органів у сфері протидії злочинності та корупції :
Наказ ГПУ від 16.01.2013 № 1/1гн. URL: https:// zakon.rada.gov.ua/rada/show/v0001900-13.

8. Віхров О.П., Віхрова І.О. Теорія держави і права : курс лекцій : навчальний посібник. Чернігів : Десна Поліграф, 2015. 304 c. URL: https://pidruchniki. com/84576/pravo/pravoviy_nigilizm.

9. Оцінка ситуації в У ціологічна група "Рейтинг» (Rating Group Ukraine). URL: http://ratinggroup.ua/research/ukraine/ocenka situacii v strane 19-22 oktyabrya_2019 goda.html?f $\bar{b}$

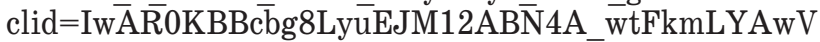
RqLOSRxfQCtLbOWYru4TgsK0I.

10. Рівень довіри до суспільних інститутів та електоральні орієнтації громадян України / Центр Разумкова. URL: http://razumkov.org.ua/ napriamky/sotsiologichni-doslidzhennia/riven-dovirydo-suspilnykh-instytutiv-ta-elektoralni-oriientatsiigromadian-ukrainy-2.

11. Пал Л. Аналіз політики / пер. з англ. Іван Дзюб. Київ : Основи, 1999. 422 с.

\section{Анотація}

Єәнак В. М. Шляхи вдосконалення форм і методів взаємодії органів прокуратури України з іншими правоохоронними органами держави. - Стаття.

У статті на основі опрацювання наукових поглядів учених і норм чинного законодавства України визначено шляхи вдосконалення форм і методів взаємодії прокуратури України з іншими правоохоронними органами держави. Доведено, що відповідна взаємодія сьогодні має низку прогалин як на законодавчому, так і практичному рівнях, що негативно позначається на якості й дієвості означеної спільної діяльності прокуратури з іншими правоохоронними органами. Визначено, що координація в контексті діяльності органів прокуратури є особливим різновидом їхньої взаємодії з іншими суб'єктами правоохоронної діяльності, насамперед правоохоронними органами, оскільки через координаційні заходи реалізується значна частина позапроцесуальної співпраці досліджуваних суб'єктів. Саме в межах координаційної діяльності вони виробляють і погоджують спільні дії щодо протидії злочинності та інших важливих питань. Наголошено, що важливим моментом удосконалення й розвитку форм і методів взаємодії органів прокуратури України з іншими правоохоронними органами держави є вироблення системи оцінювання їхньої ефективності та дієвості. Зроблено висновок, що взаємодія є важливою засадою належної реалізації прокуратурою свого функціонального призначення як правоохоронного органу, адже вона $є$ не знеособленою інституцією, а структурною ланкою національної правоохоронної системи, тому частина завдань, функцій і повноважень прокуратури передбачає іï активну взаємодію з іншими правоохоронними органами задля забезпечення більш ефективного досягнення цілей правоохоронної діяльності. Аналіз нормативно-правового підгрунтя цієї взаємодії та наукових поглядів на їі проблематику свідчать про те, що вона (взаємодія) сьогодні має низку прогалин як на законодавчому, так і практичному рівнях, що негативно позначається на якості й дієвості означеної взаємодії. Запропоновані в дослідженні кроки мають на меті вдосконалити форми й методи досліджуваної взаємодії та, відповідно, підвищити іï ефективність і результативність.

Ключові слова: форми, методи, удосконалення, взаємодія, прокуратура, правоохоронні органи, законодавство. 


\section{Summary}

However $V . M$. Ways to improve the forms and methods of interaction of the prosecutor's office of Ukraine with other law enforcement agencies of the state. - Article.

In the article on the basis of working out of scientific views of scientists and norms of the current legislation of Ukraine to determine ways of improvement of forms and methods of interaction of bodies of prosecutor's office of Ukraine with other law enforcement agencies of the state. It is proved that the relevant interaction today has a number of gaps both at the legislative and practical levels, which negatively affect the quality and effectiveness of the joint activity of the prosecutor's office with other law enforcement agencies. It has been determined that coordination in the context of the activity of the prosecuting authorities is a special kind of interaction with other law enforcement agencies, and above all law enforcement agencies. Because, through coordination activities, a significant part of the extraprocedural cooperation of the investigated entities is realized. It is within the framework of coordination activities that they produce and coordinate joint action to combat crime and other important issues. It is emphasized that an important point of improvement and development of forms and methods of interaction of the Prosecutor's Office of Ukraine with other law enforcement agencies of the state is the development of a system of evaluation of their effectiveness and efficiency. It is concluded that interaction, which is an important basis for the proper implementation by the prosecutor's office of its functional purpose as a law enforcement agency, because it is not a separate institution, but a structural link of the national law enforcement system, and therefore part of the tasks, functions and powers of the prosecutor's office interdependent bodies to better achieve law enforcement goals. The analysis of the legal basis of this interaction and the scientific views on its problems indicate that it (interaction) today has a number of gaps at both the legislative and practical levels, which negatively affect the quality and effectiveness of the interaction. The steps proposed in this study aim to improve the forms and methods of the interaction under study and, accordingly, to increase its effectiveness and efficiency.

Key words: forms, methods, improvements, interaction, prosecutor's office, law enforcement agencies, legislation. 